\title{
Effects of Adrenal Medulla and Sciatic Nerve Co-Grafts in Rats with Unilateral Substantia Nigra Lesions
}

\author{
William J. Freed, George Willingham and Robert Heim* \\ Preclinical Neuroscience Section \\ Neuropsychiatry Branch \\ NIMH Neuroscience Center at St. Elizabeths \\ 2700 Martin Luther King Ave. \\ Washington, D.C. 20032 \\ *Department of Neurosurgery \\ National Naval Medical Center \\ Bethesda, MD 20889 \\ $U S A$
}

\section{SUMMARY}

Major limitations of adrenal medulla transplantation in animal models of Parkinson's disease have been the relatively small behavioral effects and the poor or inconsistent graft survival. Transplantation of fragments of sural nerve in combination with adrenal medulla has been reported to increase the survival of chromafifin cells in adrenal medulla grafts in primates. In the present study, the possibility was tested that peripheral nerve co-grafts would increase the functional effects of adrenal medulla grafts in a 6-hydroxydopamine-lesioned rat model. Animals received unilateral substantia nigra lesions, and subsequently received intraventricular grafts of adrenal medulla, sciatic nerve, adrenal medulla plus sciatic nerve, or sham grafts consisting of medium only. Functional effects of the grafts were tested using apomorphine-induced rotational behavior. The sciatic nerve co-grafts did not increase the survival of TH-immunoreactive chromaffin cells. The co-grafting treatment also did not augment the overall effect of adrenal medulla grafts on rotational behavior. In the animals with substantial numbers of surviving

Reprint address:

William J. Freed

NIMH Neuroscience Center at St. Elizabeths

2700 Martin Luther King Ave.

Washington, D.C. 20032

USA chromaffin cells, however, the animals with sciatic nerve co-grafts showed greater decreases in rotational behavior as compared to the animals with adrenal medulla grafts alone, even though the number of surviving cells was not increased.

\section{KEY WORDS}

Parkinson's disease, adrenal medulla, grafts, brain grafts, transplantation, substantia nigra, chromaffin cells

\section{INTRODUCTION}

Transplantation of adrenal medulla into the brain has been reported to alleviate some of the consequences of substantia nigra (SN) lesions in animals $/ 4,6,10,17,19,30,32 /$, and has attracted considerable attention as a possible treatment for Parkinson's disease /20, 23, 24/. Major limitations of adrenal medulla transplantation, which may relate to its limitations as a potential clinical procedure, have been the relatively small behavioral effects which are seen in animals and the poor or inconsistent graft survival /19/.

Recently, Kordower and coworkers /22/ reported that, in primates, transplantation of fragments of sural nerve in combination with adrenal medulla tissue increased the survival of tyrosine 
hydroxylase (TH)-immunoreactive chromaffin cells by more than four-fold. Similar results, in addition to increased functional effects in animals receiving the co-grafts, have been reported by Watts et al. /38/. Sural nerve was used for co-transplantation because of the ability of Schwann cells to release nerve growth factor (NGF) following nerve transection $/ 21,33 /$. Prior studies had obtained improved survival and efficacy of intraparenchymal adrenal medulla grafts when combined with NGF infusions /31/. NGF infusions have also recently been tried in combination with adrenal medulla grafts in human patients $/ 26 /$.

Several additional studies have reported that graft survival or functional effects are improved by a variety of co-transplantation techniques. Transplantation of fragments of adrenal medulla in combination with peripheral nerve has been reported to increase chromaffin cell survival and recovery of TH-immunoreactive fibers in surrounding tissue, in mice with 1-methyl-4-phenyl1,2,3,6-tetrahydropyridine-induced lesions $/ 9 /$. In animals with unilateral SN lesions, co-grafts of peripheral nerve have been found to increase the functional efficacy of fetal substantia nigra grafts $17,36 /$, but not of intraparenchymal grafts of adrenal medulla tissue $/ 35 /$. Bing et al. $/ 5 /$ reported that the survival and efficacy of grafts of adrenal chromaffin cells is improved by co-transplantation with amitotic $\mathrm{C} 6$ glioma cells, which also have the capacity to secrete NGF. Doering and Tokiwa /11/ have reported consistent adrenal chromaffin cell survival after transplantation into peripheral nerve. Therefore, although several studies report increased graft survival or histochemical changes, peripheral nerve co-grafts have not been reported to enhance the functional effects of adrenal medulla grafts in a 6-hydroxydopamine-lesioned rat model.

\section{MATERIALS AND METHODS}

Adult male Sprague-Dawley rats (Zivic Miller Laboratories, Inc.), initial weight $125-150 \mathrm{~g}$, were housed in groups of at least two under controlled temperature and lighting conditions with continuous access to food and water, and maintained according to the NIH Guide for the Care and Use of Laboratory Animals. Dopaminergic neurons in the right SN pars compacta were destroyed by unilateral stereotaxic infusion of 6-hydroxydopamine hydrobromide under ketamine and xylazine anesthesia as previously described /18/. Fourteen days after lesioning the rats underwent testing for rotational behavior $/ 34$ / in response to administration of apomorphine $\mathrm{HCl}(0.1 \mathrm{mg} . \mathrm{kg}$ s.c.). Rotational behavior was measured in cylindrical rotometer devices with flat bottoms as described elsewhere /14/. Forty-eight animals that rotated a minimum of 120 times in one hour following administration of apomorphine were selected and were retested six times over the course of 12 weeks. The rats were coded and randomly assigned to four equal groups of 12 animals each, and each group was designated to receive grafts of either adrenal medulla, sciatic nerve, adrenal medulla plus sciatic nerve, or sham grafts consisting of medium only $(20 \mu 1$ lactated Ringer's solution).

Host animals were anesthetized with $70 \mathrm{mg} / \mathrm{kg}$ ketamine and $6 \mathrm{mg} / \mathrm{kg}$ xylazine i.m., received 0.1 $\mathrm{ml}$ Flo-Cillin i.m. and $0.04 \mathrm{mg} / \mathrm{kg}$ atropine s.c., and were mounted in a stereotaxic instrument. The tissue donors were young male Sprague-Dawley rats 4-5 weeks of age weighing $100-150 \mathrm{~g}$. Donors were anesthetized with ketamine and xylazine, and the adrenal glands and sciatic nerves were removed and bathed in sterile lactated Ringer's solution. The adrenal capsule and cortex were removed under a dissecting microscope. The adrenal medulla and sciatic nerve were cut into 2 pieces each. Two adrenal medullae, an equivalent amount of sciatic nerve, or both tissues combined (co-grafts) were implanted. The co-graft group received two adrenal medullae plus an equivalent amount of sciatic nerve, or approximately twice the total quantity of tissue that was implanted in the adrenal medulla or sciatic nerve-only groups. Tissue was implanted into the right lateral ventricle of the host animals through an 18 gauge needle, as previously described $/ 14,15 /$. The stereotaxic coordinates were $1.5 \mathrm{~mm}$ anterior and $1.5 \mathrm{~mm}$ lateral to the bregma and $4.5 \mathrm{~mm}$ below the dura, with the bite bar set at $5.0 \mathrm{~mm}$ above the interaural line.

The rats were maintained for a period of 13 weeks following the grafting procedure. Three of 
the twelve animals in the co-graft group died of unknown causes during the four weeks after transplantation. All 36 grafted rats in the other three groups survived for the entire period. Apomorphine-induced rotational behavior was tested at four, six, eight, ten, and twelve weeks post grafting. At each time period, three tests were conducted over the course of 6-8 days, with an interval of at least two days between tests. The mean for each time period was used, and compared to the mean of all six pregrafting tests.

One week after completion of the 12 week rotation testing, the rats were sacrificed for histology. Animals were anesthetized with ketamine and xylazine and perfused with saline followed by 4\% paraformaldehyde. Brains were equilibrated in $10 \%$ followed by $30 \%$ sucrose solutions, frozen, sectioned on a cryostat at $12 \mu \mathrm{m}$, and mounted three sections per slide. Every sixth slide was stained with cresyl violet and examined to determine the approximate graft location. Every third slide was then processed for TH immunocytochemistry, and numbers of TH-immunoreactive cells were counted on every ninth $12 \mathrm{~mm}$ section. The sections were washed with TRIS buffered saline (TBS), and immersed in 100\% methanol. Following additional TBS rinsing, the sections were immersed in 3\% horse serum (Gibco heat-inactivated normal horse serum) in TBS for 30 minutes. The sections were incubated in primary antibody (1:1000 Boehringer Monoclonal anti-TH) overnight. After rinsing (TBS, 3 x 30 sec), biotinylated secondary antibody (1:100 Amersham anti-mouse IgG, biotinylated speciesspecific) was applied for 60 minutes at room temperature, and the slides were rinsed. Finally, the sections were treated with fluorescein-labeled streptavidin (1:100, Amersham) for 60 minutes, rinsed, and examined under a fluorescence microscope.

The total number of TH-positive cells in each graft was estimated from the raw cell counts in the serial sections, correcting for total cell numbers by the Abercrombie method 1 formula $1 /$. The same correction factor (total counts $=$ raw cell count $\mathrm{X}$ 10.8) was used for all of the animals.

Analysis of variance was performed with the aid of the SuperANOVA program (Abacus Concepts, Inc., Berkeley, California, 1989), as detailed in results. Other statistical tests were performed with the aid of the StatView 512+ program.

\section{RESULTS}

Following transplantation, all groups of rats tended to show gradual increases in rotational behavior (Fig. 1). The smallest increase was seen in the group that received adrenal medulla plus sciatic nerve co-grafts, although the differences between groups were not statistically significant (cf. Fig. 1 legend).

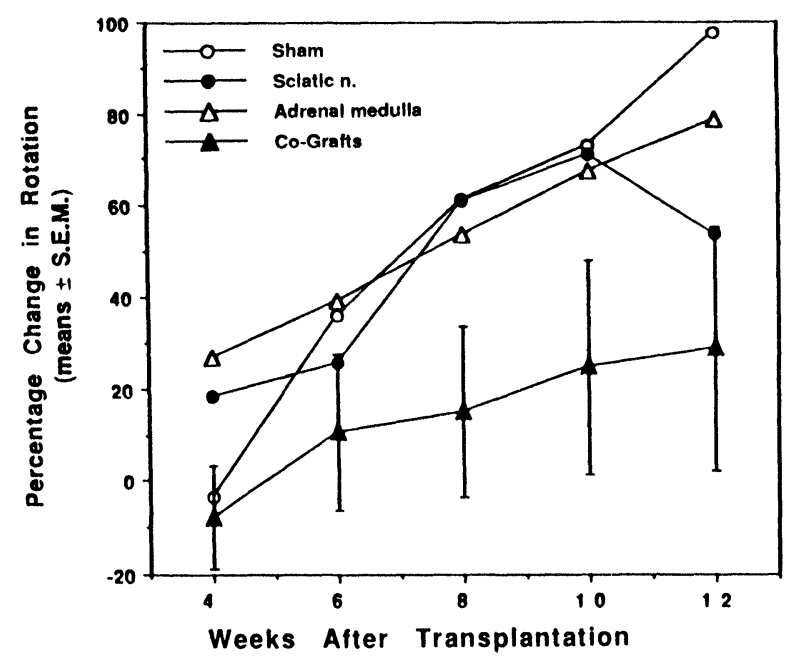

Fig. 1: Percentage changes in apomorphine-induced rotational behavior as a function of time in weeks after transplantation. Groups received grafts of sciatic nerve (closed circles), adrenal medulla (open triangles), adrenal medulla and sciatic nerve combined (co-grafts; closed triangles), or a sham injection of lactated Ringer's solution (open circles). Data shown are means; standard errors are shown for the co-graft group for clarity. A three-way ANOVA for one repeated measure (time) and two between-group measures (adrenal graft vs. vehicle, and sciatic nerve vs. vehicle) showed no significant main effects of the presence or absence of either the adrenal medulla $(F(1,40)=0.90 ; p=0.35)$ or sciatic nerve $(F(1,40)=1.94 ; p=0.17)$ grafts. The main effect of time was statistically significant $(F(4,160)=11.88$; $p<0.0001$ ), but none of the interactions involving adrenal medulla or sciatic nerve graft effects with time was significant (all $p>0.3$ ). Means contrasts comparing sciatic nerve or adrenal medulla graft orthogonal effects for the individual groups were also not significant (all $p>0.1$ ). Of these, the smallest probability value obtained was for the effect of sciatic nerve grafts in animals with adrenal medulla grafts $(p=0.12)$. 
Histologically, substantial numbers of TH-immunoreactive cells were found in only about half of the graft recipients. Grafts in both the adrenal medulla and co-graft groups were similar (Fig. 2), although the TH + cells in the adrenal medullaonlv grafts appeared to have relatively round shapes and few processes (Fig. 2a, b), whereas there was a tendency for some $\mathrm{TH}+$ cells in the co-graft group to have more elongated cell shapes (Fig. 2c, d). In the animals with adrenal medulla grafts, grafts with more than 100 surviving $\mathrm{TH}+$ cells were found in six of the 12 graft recipients, no surviving cells were found in four animals, and the largest number of $\mathrm{TH}+$ cells was 1744 . In the co-graft group, more than 100 surviving cells were found in only three of the nine surviving animals, zero $\mathrm{TH}+$ cells were found in three animals, and the largest number of surviving cells was $\mathbf{5 7 2}$. Three animals, one in the co-graft group and two in the adrenal medulla graft group, had misplaced grafts in the septum, corpus callosum, or cortex. The mean ( \pm S.E.M.) number of (appropriatelylocated) surviving $\mathrm{TH}+$ cells was $442 \pm 161$ for the adrenal medulla-grafted animals and $163 \pm 80$ for the co-grafted animals. This difference was not statistically significant $\left(t_{(19)}=1.40 ; p=0.18\right.$, twotailed).

The data were analyzed to determine whether there were differences in recovery of rotational behavior between the animals with vs. without surviving TH-immunoreactive cells, in the adrenal medulla alone as compared to the adrenal medulla plus sciatic nerve co-graft group. Animals were classified according to whether they had less than, or more than, 100 surviving TH-immunoreactive cells. A two-way analysis of variance, using as between-group factors (a) type of graft, and (b) more than vs. less than 100 surviving cells, was performed, using the percentage change in rotation after 12 weeks as the dependent variable. Because of the large increases in rotation, five of the animals with relatively low initial rates of rotation showed increases in rotation after 12 weeks of more than two-fold, i.e., percentage changes of greater than positive $100 \%$ ( +116 to $264 \%$ ). Because the three highest values tended to distort the means, a value of positive $100 \%$ was substituted for each of the increases exceeding positive $100 \%$. This resulted in an equal possible range of values of 100 percentage points in both the positive and negative direction.

In the animals with adrenal medulla grafts the mean percentage changes in rotation after 12 weeks were $+60.2 \%$ for the animals with less than 100 surviving cells and $+48.8 \%$ for the animals with more than 100 surviving cells. For the cograft animals with less than 100 surviving cells, the change in rotation was $+40.0 \%$, as compared to $-28.0 \%$ for the animals with greater than 100 surviving cells (Fig. 3). There was a significant main effect of graft type (adrenal medulla vs. co-grafts: $\left.F_{(1,17)}=5.26 ; p=0.035\right)$, but the overall main effect of number of surviving cells was not significant $\left(F_{(1,17)}=3.52 ; p=0.078\right)$. The graft type vs. surviving cell interaction was not significant $\left(F_{(1,17)}=1.80 ; p=0.20\right)$. Means contrasts were performed for each of the orthogonal group comparisons. The effect of number of surviving cells in the animals with adrenal medulla grafts was not significant $(p=0.68)$, nor was the effect of graft type in the animals with less than 100 surviving cells $(p=0.46)$. Within the co-graft group, there was a tendency for the animals with more than 100 surviving cells to show greater decreases in rotation $(\mathrm{p}=0.053)$. For the comparison of adrenal medulla vs. co-graft animals with more than 100 surviving cells, however, the animals with co-grafts showed significantly greater reductions in rotational behavior than the corresponding animals with adrenal medulla-only grafts $(p=0.031$; $c$. Fig. 3).

\section{DISCUSSION}

There are several aspects of the present data which are inconsistent with previous reports. First, the adrenal medulla-only grafts did not decrease rotational behavior, even if only the animals with surviving chromaffin cells were considered. The reason for this discrepancy is unknown. It is possible that tissue from the relatively young sexually immature donors that were used is not optimal. It is also possible that the ability of chromaffin cell grafts to decrease rotational behavior is dependent upon very specific testing conditions. For example, the testing of rotational behavior at regular intervals, as was 

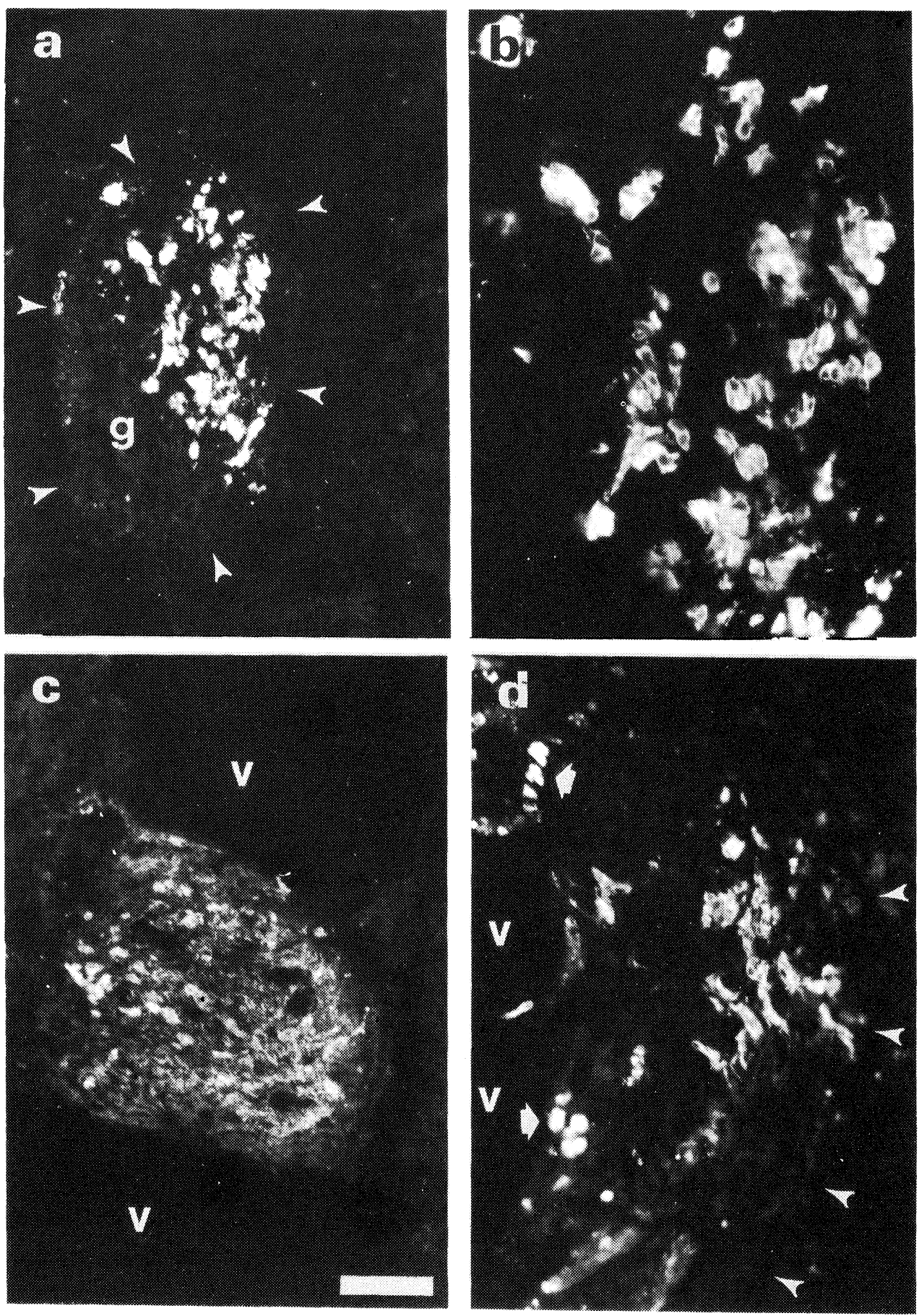

Fig. 2: Tyrosine hydroxylase-immunoreactive chromaffin cells in adrenal medulla grafts ( $\mathbf{a}$ and $\mathbf{b}$ ) and in adrenal medullasciatic nerve co-grafts (c and d). (a) Low magnification of an adrenal medulla graft (g) in the lateral ventricle, slightly overexposed to show the general graft location and appearance. Arrowheads indicate the border of the graft. (b) Higher magnification of the same field seen in a, showing the generally round shape of most of the TH-immunoreactive cells. (c) Low magnification photograph, showing the general appearance of a co-graft in the lateral ventricle (v). (d) Higher magnification of TH-immunoreactive cells in a co-graft recipient. The irregularly shaped cells on the left of the photograph (arrows) are autofluorescent macrophages. Some of the chromaffin cells have elongated or irregular shapes, and a few TH-immunoreactive processes are present. The lateral ventricle (v) can be seen on the left, and the approximate border of the graft on the right is indicated by the arrowheads. Calibration $=100 \mu \mathrm{m}$ for $\mathbf{a}$ and $\mathrm{c}, 40 \mu \mathrm{m}$ for $\mathrm{b}$, and $62.5 \mu \mathrm{mi}$ for $\mathrm{d}$. 


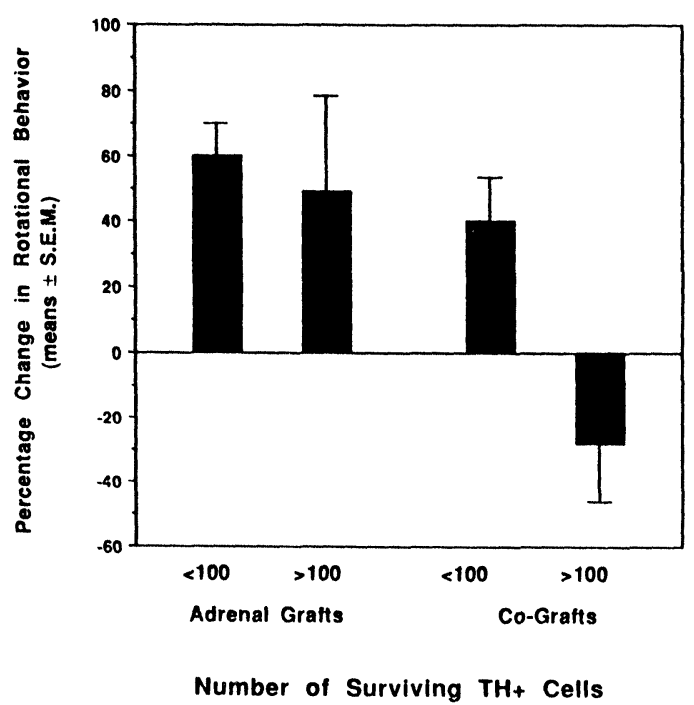

Fig. 3: Changes in rotational behavior from before to 12 weeks after transplantation in animals that received either adrenal medulla grafts or co-grafts, classified according to whether they had less than 100 or more than 100 surviving TH-immunoreactive chromaffin cells. After this group subdivision, the maximum uncorrected cell count was 15 (corrected count $=81$ ) for the animals with less than 100 surviving cells, and the minimum cell count was 55 (corrected count $=297$ ) in the animals with more than 100 surviving cells. Statistics are given in the text: For the animals with more than 100 surviving cells, the animals with co-grafts showed significantly greater reductions in rotational behavior than the animals with adrenal medulla-only grafts $(p=0.031)$.

used in the present experiment, might be incompatible with detecting the small effects of adrenal medulla grafts. Several studies have reported sensitization to apomorphine-induced effects, including rotational behavior, with repeated administration $/ 2,8,25,37 /$. Progressive increases in apomorphine-induced rotation have also occasionally been observed in prior transplantation experiments, when the animals are tested repeatedly at regular intervals, as in the present experiment $/ 12,16 /$. It should also be noted that rotation increased somewhat over the course of the six pre-transplantation sessions, so that greater decreases would have been observed in all four groups if, for example, only the final three pre- transplantation sessions (rather than all six) had been used for data analysis. Regardless of the absolute magnitude of the changes, however, the adrenal medulla and sham groups were very similar at all post-transplantation time points.

Secondly, the co-transplantation technique did not result in increased chromaffin cell survival. Several other studies have reported that combining sciatic nerve with adrenal medulla grafts increases chromaffin cell survival $/ 9,11,22,38 /$. One possible explanation for this discrepancy is that the method of transplantation used in the present study might not have been optimal for enhancement of chromaffin cell survival by the sciatic nerve co-grafts. Since the co-grafts consisted of separate fragments of sciatic nerve and adrenal medulla, there may have been limited contact between the tissues, which might not be optimal for NGF or other trophic substances secreted by the sciatic nerve fragments to come into contact with the transplanted chromaffin cells. In addition, the intraventricular transplantation technique might permit NGF secreted from nerve tissue fragments to escape into the cerebrospinal fluid.

On the other hand, in the animals with significant numbers of surviving chromaffin cells, the co-grafted animals did show enhanced decreases in rotational behavior. Since this behavioral effect was not related to increased chromaffin cell survival, it appears that sciatic nerve grafts were able to exert an effect independent of that produced by the adrenal medulla grafts, which was, however, manifest only when surviving $\mathrm{TH}+$ chromaffin cells were also present. It is also possible that larger effects would have been observed if a greater proportion of the transplanted cells had survived.

The present data could be interpreted as being generally consistent with the findings of Pezzoli $e t$ al. $/ 28 /$, who reported that adrenal medulla grafts produced moderate effects on rotational behavior by themselves. When grafts of adrenal medulla were combined with infusions of NGF, greatly enhanced effects on rotational behavior were seen. In the Pezzoli et al. /28/ study, the enhancing effect of NGF infusions did not require adrenal medulla grafts, but was also present when grafts of other tissues, such as sciatic nerve or adipose tissue, were used in combination with NGF infu- 
sions. NGF infusions alone were not effective. The reasons for this and other apparent trophic effects of these grafts are unknown. Suggestions have included interactions involving macrophages, interleukins, and NGF $/ 3,6,13 /$, secretion of basic fibroblast growth factor $/ 27 /$, or production of cell adhesion molecules $/ 29 /$. The present finding, that sciatic nerve and adrenal medulla produced an effect on rotational behavior only when the two tissue types were combined, is particularly reminiscent of the Pezzoli et al. /28/ data.

Even more consistent with the present data is a recent study by van Horne et al. $/ 36 /$, who reported that co-transplantation of fragments of sciatic nerve increased the effect of $\mathrm{SN}$ grafts on rotational behavior, without any apparent effect on cell survival. Notwithstanding the fact that adrenal medulla grafts generally produce smaller effects than do grafts of $\mathrm{SN}$, this finding / $36 /$ is very similar to the findings of the present study. Subsequently, Collier and Springer /7/ found that sciatic nerve grafts augmented the decreases in amphetamine-induced rotation following $\mathrm{SN}$ grafts, and in their study augmentation of the reafferentation of host brain by the grafts was also reported. These data suggest that the enhancing effect of sciatic nerve co-grafts is not specific for adrenal medulla, and is also seen when peripheral nerve grafts are combined with grafts of other tissues, including SN. Van Horne and coworkers /35/ have also reported that sciatic nerve co-grafts did not increase the effects of intraparenchymal adrenal medulla grafts. In the present study, no enhancing effect of sciatic nerve co-grafting on adrenal medulla grafts was detected, except when only the animals with substantial numbers of surviving chromaffin cells were considered.

Therefore, co-grafts of adrenal medulla and sciatic nerve did not produce larger effects than grafts of adrenal medulla alone, when all animals were considered together. In the present study, the sciatic nerve co-grafts also failed to increase the survival of transplanted chromaffin cells. When only the subgroups of animals with a substantial number of surviving $\mathrm{TH}+$ chromaffin cells were considered, however, the co-grafts produced significantly larger effects than comparable grafts of adrenal medulla alone. These data support the possibility that combining grafts of adre- nal medulla with peripheral nerve is capable of producing increased functional effects.

\section{REFERENCES}

1. Abercrombie M. Estimation of nuclear population from microtome sections. Anat Rec 1946; 94: 239-247.

2. Bailey RC, Jackson DM. A pharmacological study of changes in central nervous system receptor responsiveness after long-term dexamphetamine and apomorphine administration. Psychopharmacology 1978; 56: 317-326.

3. Bankiewciz KS, Plunkett RJ, Kopin IJ, Jacobowitz DM, London WT, Oldfield EH. Transient behavioral recovery in hemiparkinsonian primates after adrenal medullary autografts. In: Gash DM, Sladek JR, eds, Transplantation in the Mammalian CNS. Prog Brain Res 1988; 78: 507-511.

4. Becker JB, Freed WJ. Adrenal medulla grafts enhance functional activity of the striatal dopamine system following substantia nigra lesions. Brain Res 1988; 462: 401-406.

5. Bing G, Nother MFD, Hansen JT, Kellogg C, Kordower JH, Gash DM. Cografts of adrenal medulla with C6 glioma cells in rats with 6-hydroxydopamineinduced lesions. Neuroscience 1990; 34: 687-697.

6. Bohn MC, Marciano F, Cupit L, Gash DM. Adrenal medullary grafts promote recovery of striatal dopaminergic fiber in MPTP treated mice. Science 1987; 237: 913-916.

7. Collier TJ, Springer JE. Co-grafts of embryonic dopamine neurons and adult sciatic nerve into the denervated striatum enhance behavioral and morphological recovery in rats. Exp Neurol 1991; 114: 343-3509.

8. Costentin J, Protais P, Schwartz JC. Rapid and dissociated changes in sensitivities of different dopamine receptors in mouse brain. Nature 1975; 257: 405-407.

9. Date I, Felten SY, Felten DL. Cografts of adrenal medulla with peripheral nerve enhance the survivability of transplanted adrenal chromaffin cells and recovery of the host nigrostriatal dopaminergic system in MPTP-treated young adult mice. Brain Res 1990; 537: 33-39.

10. Decombe R, Rivot JP, Aunis D, Abrous N, Peshanski $M$, Herman JP. Importance of catecholamine release for the functional action of intrastriatal implants of adrenal medullary cells: Pharmacological analysis and in vivo electrochemistry. Exp Neurol 1990; 107: !43153.

11. Doering LC, Tokiwa MA. Adrenal medulla and substantia nigra co-grafts in peripheral nerve: Chromaffin cells survive for long time periods and prevent degeneration of nigral neurons. Brain Res 1991; 551: 267 278.

12. Dunnett SB, Bjorklund A, Schmidt RH, Stenevi U, Iversen SD. Intracerebral grafting of neuronal cell suspensions. IV. Behavioral recovery in rats with uni- 
lateral 6-OHDA lesions following implantation of nigral cell suspensions in different forebrain sites. Acta Physiol Scan Suppl 1983; 522: 29-37.

13. Fiandaca MS, Kordower JH, Hansen JT, Jiao S-S, Gash DM. Adrenal medullary autografts into the basal ganglia of cebus monkeys: Injury-induced regeneration. Exp Neurol 1988; 102: 76-91.

14. Freed WJ. Functional brain tissue transplantation: Reversal of lesion-induced rotation by intraventricular substantia nigra and adrenal medulla grafts, with a note on intracranial retinal grafts. Biol Psychiat 1983; 18: $1205-1267$.

15. Freed WJ. Transplantation of tissues to the cerebral ventricles: Methodological details and rate of graft survival. In: Bjorklund A, Stenevi $U$, eds, Neural Grafting in the Mammalian CNS, Chapter 4. Amsterdam: Elsevier Science Publishers B.V., 1985; 31-40.

16. Freed WJ, Adinolfi AM, Laskin JD, Geller HM. Transplantation of B16/C3 melanoma cells into the brains of rats and mice. Brain Res 1989; 485: 349-362.

17. Freed WJ, Morihisa J, Spoor E, Hoffer B, Olson L, Seiger A, Wyatt RJ. Transplanted adrenal chromaffin cells in rat brain reduce lesion-induced rotational behavior. Nature 1981; 292: 351-352.

18. Freed WJ, Perlow MJ, Karoum F, Seiger A, Olson L, Hoffer BJ, Wyatt R. Restoration of dopaminergic function by grafting of fetal rat substantia nigra to the caudate nucleus: Long term behavioral, biochemical, and histochemical studies. Ann Neurol 1980; 8: 510519.

19. Freed WJ, Poltorak M, Becker JB. Intracerebral adrenal medulla grafts: A review. Exp Neurol 1990; 110: 139-166.

20. Goetz CG, Stebbins GT, Klawans HL, Koller WC, Grossman RG, Bakay RAE, Penn RD, the United Parkinson Foundation Transplantation Registry. United Parkinson Foundation Neurotransplantation Registry on adrenal medullary transplants: Presurgical, and 1- and 2-year follow-up. Neurology 1991; 41: 1719-1722.

21. Heumann R, Korsching S, Bandtlow C, Thoenen $\mathbf{H}$. Changes of nerve growth factor synthesis in nonneuronal cells in response to sciatic nerve transection. J Cell Biol 1987; 104: 1623-1631.

22. Kordower JH, Fiandaca MS, Notter MFD, Hansen JT, Gash DM. NGF-like trophic support from peripheral nerve for grafted rhesus adrenal chromaffin cells. J Neurosurg 1990; 73: 418-428.

23. Lindvall O, Backlund E-O, Farde L, Sedvall G, Freedman R, Hoffer B, Nobin A, Seiger A, Olson L. Transplantation in Parkinson's disease: Two cases of adrenal medullary grafts to the putamen. Ann Neurol 1991; 22: 457-468.

24. Madrazo I, Drucker-Colin R, Diaz V, Martinez-Marta J, Torres C, Becerril JJ. Open microsurgical autograft of adrenal medulla to the right caudate nucleus in Parkinson's disease: A report of two cases. N Engl J Med 1987; 316: 831-834.

25. Norman AB, Wyatt LM, Hildebrand JP,
Kolmonpunporn M, Moody CA, Lehman MN, Sanberg PR. Sensitization of rotational behavior in rats with unilateral 6-hydroxydopamine or kainic acidinduced striatal lesions. Pharmacol Biochem Behav 1990; 37: 755-759.

26. Olson L, Backlund E-O, Ebendal T, Freedman R, Hamberger B, Hansson P, Hoffer B, Lindblom U, Meyerson B, Stromberg I, Sydow O, Seiger A. Intraputamenal infusion of nerve growth factor to support adrenal medullary autografts in Parkinson's disease: One year follow up of first clinical trial. Arch Neurol 1991; 48: 373-381.

27. Otto D, Unsicker K. Basic FGF reverses chemical and morphological deficits in the nigrostriatal system of MPTP treated mice. J Neurosci 1990; 10: 1912-1921.

28. Pezzoli G, Fahn S, Dwork A, Truong DD, de Yebenes JG, Jackson-Lewis V, Herbert J, Cadet JL. Non-chromaffin tissue plus nerve growth factor reduces experimental parkinsonism in aged rats. Brain Res 1988; 459: 398-403.

29. Poltorak M, Freed WJ. Cell adhesion molecules in adrenal medulla grafts: Enhancement of chromaffin cell $\mathrm{L} 1 / \mathrm{Ng}-\mathrm{CAM}$ expression and reorganization of extracellular matrix following transplantation. Exp Neurol 1990; 100: 73-85.

30. Simonds GW, Schwarz S, Krauthamer E, Freed WJ. Effects of adrenal medulla grafts in neonatal rat hosts on subsequent bilateral substantia nigra lesions. Restor Neurol Neurosci 1990; 1: 315-322.

31. Stromberg I, Herrera-Marschitz M, Ungerstedt U, Ebendal T, Olson L. Chronic implants of chromaffin tissue into the dopamine-denervated rat striatum. Effects of NGF on graft survival, fiber growth, and rotational behavior. Exp Brain Res 1985; 60: 335-349.

32. Takashima H, Poltorak M, Becker JB, Freed WJ. Effects of adrenal medulla grafts on plasma catecholamines and rotational behavior. Exp Neurol 1992; (in press).

33. Taniuchi M, Clark HB, Schweizer JB, Johnson EM Jr. Expression of nerve growth factor receptors by Schwann cells of axotomized peripheral nerves: Ultrastructural location, suppression by axonal contact, and binding properties. J Neurosci 1988; 8: 664-681.

34. Ungerstedt U, Arbuthnott GW. Quantitative recording of rotational behavior in rats after 6-hydroxy-dopamine lesions of the nigrostriatal dopamine system. Brain Res 1970; 24: 485-493.

35. van Horne CG, Stromberg I, Wittenberg WL, Hudson J, Olson L, Hoffer B. Functional enhancement of intrastriatal dopamine cell grafts but not chromaffin cell grafts by the co-transplantation of sciatic nerve tissue in 6-hydroxydopamine lesioned rats. Soc Neurosci Abst 1990; 16: 655.

36. van Horne CG, Stromberg I, Young D, Olson L, Hoffer B. Functional enhancement of intrastriatal dopamine-containing grafts by the co-transplantation of sciatic nerve tissue in 6-hydroxydopamine-lesioned rats. Exp Neurol 1991; 113: 143-154.

37. Vaughn DM, Severson JA, Woodward JJ, Randall PK, 
Riffee WH, Leslie SW, Wilcox RE. Behavioral sensitization following subchronic apomorphine treatment - possible neurochemical basis. Brain Res 1990; 526: 37-44.

38. Watts RL, Bakay RAE, Herring CJ, Sweeney KM, Colbassani HJ, Mandir A, Byrd LD, Iuvone PM. Preliminary report on adrenal medullary grafting and cografting with sural nerve in the treatment of hemiparkinson monkeys. Prog Brain Res 1990; 82: 581-591. 

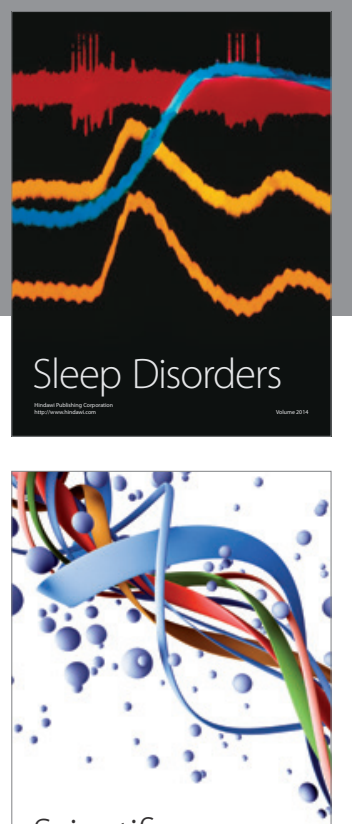

Scientifica
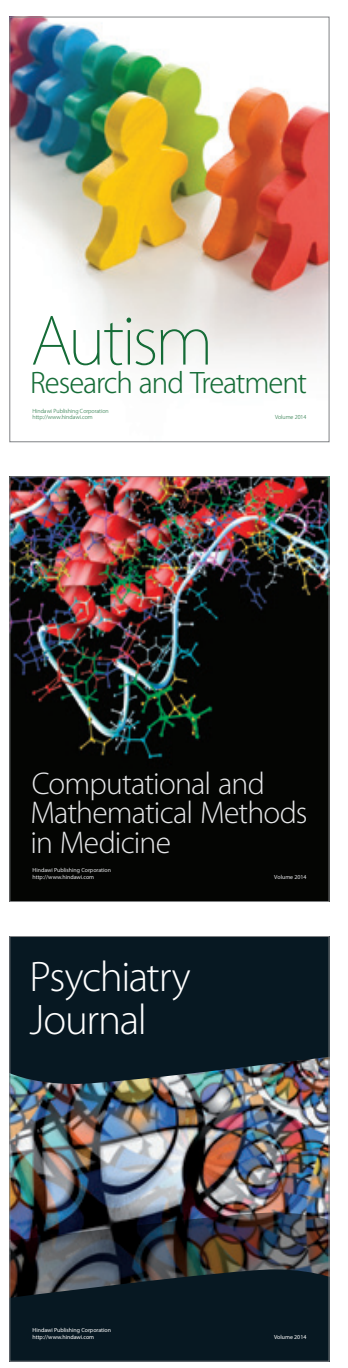
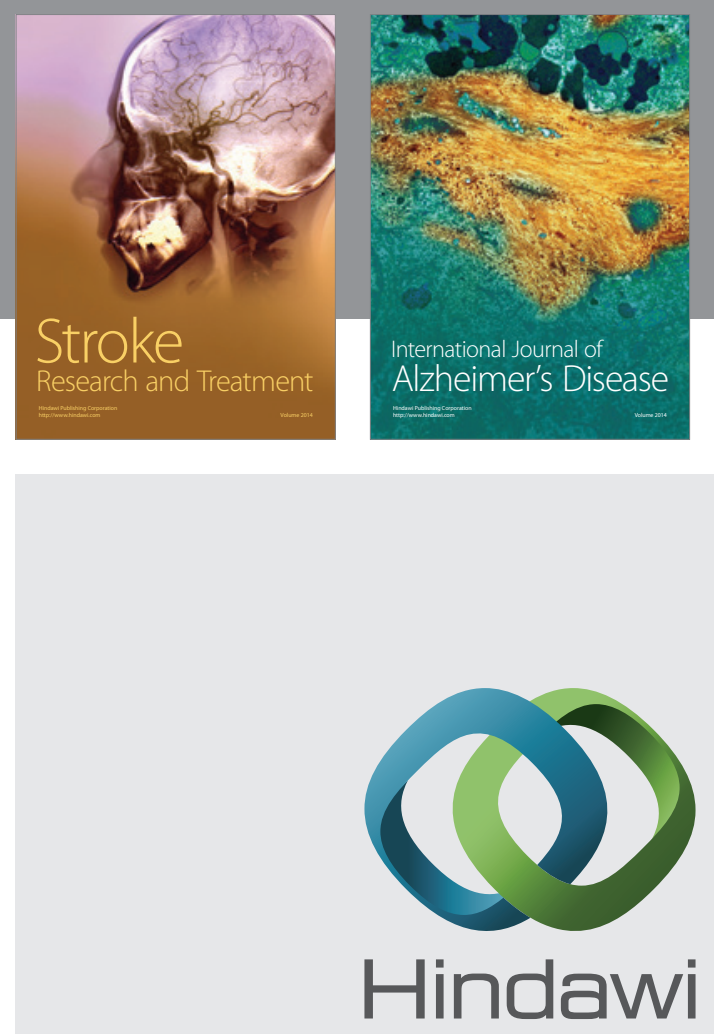

Submit your manuscripts at

http://www.hindawi.com
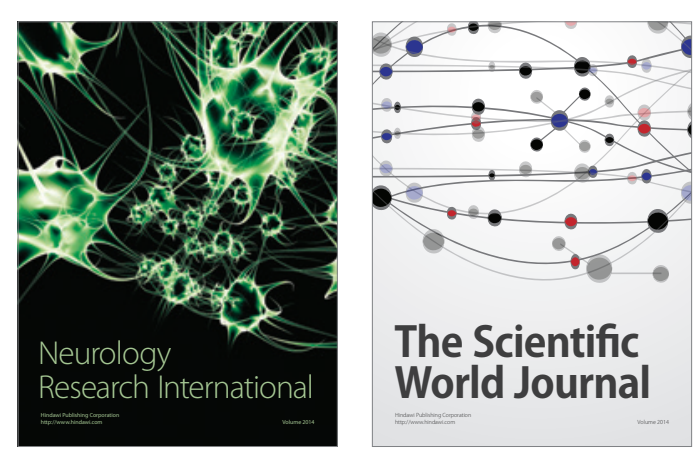

The Scientific World Journal

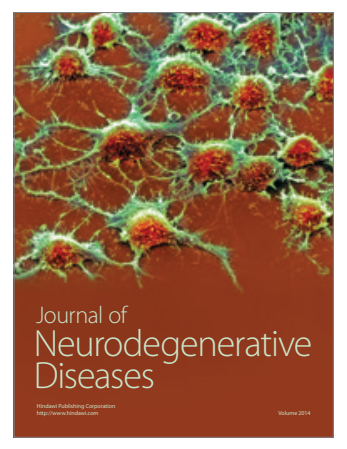

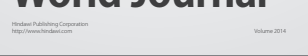

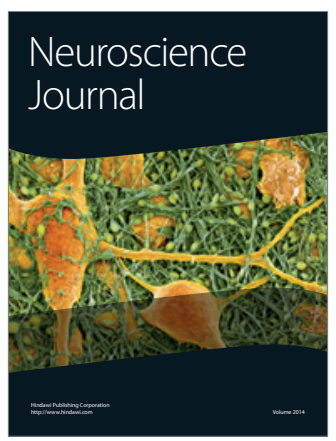

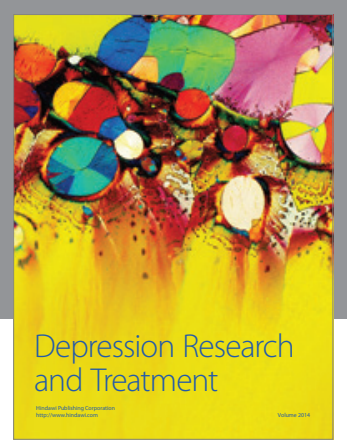
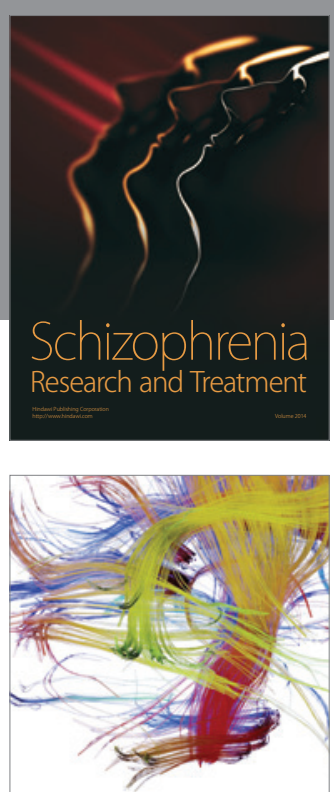

Brain Science

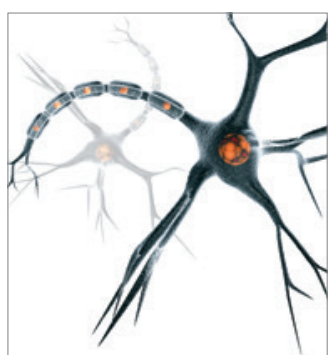

Neural Plasticity
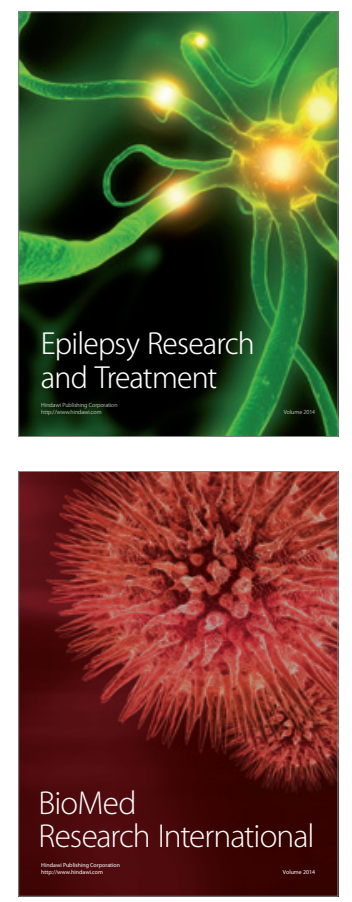

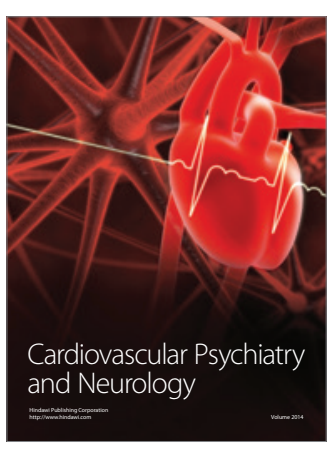

Parkinson's

Disease
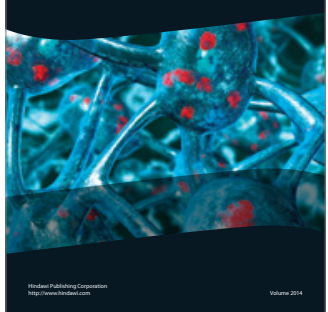